\title{
Trace Elements in the Urine of Diabetics Determined by Instrumental Neutron Activation Analysis ${ }^{\dagger}$
}

\author{
Tadashi IsHII, Kimiko HoRIUCHI, Hiromichi NAKAHARA \\ and Yukio MuRAKAMI \\ Department of Chemistry, Faculty of Science, Tokyo Metropolitan University \\ Fukasawa 2-1, Setagaya-ku, Tokyo 158 \\ Received March 19, 1980
}

Key Words: urine, diabetes, neutron activation analysis

\section{Introduction}

Recently, much research has been carried out in an attempt to correlate the concentrations of trace elements in the body and various diseases ${ }^{11}$. Blood, serum and hairs are most commonly regarded as possible indicators of trace element variations within the body since they are easy to obtain and select. However, urine is also easy to obtain and can be another possible indicator especially for the patients suffering from kidney malfunction although it is very susceptible to diet.

In this work, trace-element analysis was performed on the urine samples of both the normal men and the patients diagnosed as diabetes in order to see if there were any correlations between the trace-element contents in urine and the disease. As it is desirable to determine as many elements as possible from the same sample, instrumental neutron activation analysis was employed.

\section{Experimental}

Samples Urine samples from thirty-four patients and seven normal men were analyzed. Since each sample had more or less residues, a few $\mathrm{m} l$ of conc. $\mathrm{HNO}_{3}$ of analytical grade was added and stirred until the urine became seem-

†放射化分析に上る糖尿病患者の尿中の微量元素の 定量. 石井 忠, 堀内公子, 中原弘道, 村上悠紀 雄: 東京都立大学理学部化学教室, 158 東京都世 田谷区深沢2-1-1 ingly clear. Then, $10 \mathrm{~m} l$ of each sample solution was pipetted into a quartz evaporation dish and one $\mathrm{m} l$ of $\mathrm{HNO}_{3}$ was further added. The dish was placed in a quartz tube in nitrogen atmosphere and heated gently from outside by infrared lamps. The heating was continued until the organic substance was almost completely ashed and slightly yellowish white residue was obtained. The total amount of the residue was weighed and about $50 \mathrm{mg}$ was doubly sealed in polyethylene bags for neutron irradiation. As standards, GSJ JB-1 and JG-1 reference rocks (about 50mg each) were used for the determination of $\mathrm{Na}, \mathrm{Mg}, \mathrm{Al}, \mathrm{K}, \mathrm{Sc}, \mathrm{V}, \mathrm{Fe}, \mathrm{Co}$ and $\mathrm{Rb}$.

For $\mathrm{Cl}, \mathrm{Cr}, \mathrm{Zn}, \mathrm{Se}, \mathrm{Br}$ and $\mathrm{Cs}$ standard solutions of appropriate concentrations were prepared from the respective reagents of analytical grade and $50 \mu l$ to $100 \mu l$ were pipetted onto small pieces of filter paper and dried at room temperature.

Irradiation Neutron irradiations were carried out in the TRIGA MARK II Reactor of St. Pauls'. Three kinds of irradiation periods, 5 $\min , 6 \mathrm{hr}, 24 \mathrm{hr}$, were chosen depending on the half-lives of the product nuclides. The neutron flux was in the range of $5.0 \times 10^{11}$ to $1.2 \times 10^{12}$ $\mathrm{n} / \mathrm{cm}^{2} \cdot \mathrm{sec}$.

Activity measurement The gamma rays emitted from the product nuclides were measured by a $40 \mathrm{cc} \mathrm{Ge}(\mathrm{Li})$ detector connected to a 2048 channel pulse height analyser. The half lives and the gamma-ray energies used for the determination are shown in Table 1. 
Table 1 The content in trace elements in human urine $(\mu \mathrm{g} / \mathrm{ml})$

\begin{tabular}{|c|c|c|c|c|c|c|c|c|c|}
\hline \multirow{2}{*}{ Element } & \multirow{2}{*}{ Nuclide } & \multirow{2}{*}{$\begin{array}{l}\text { Energy } \\
(\mathrm{keV})\end{array}$} & \multirow{2}{*}{$T_{1 / 2}$} & \multicolumn{3}{|c|}{ Diabetes } & \multicolumn{3}{|c|}{ Normal } \\
\hline & & & & range & average & $\sigma$ & range & average & $\sigma$ \\
\hline $\mathrm{Na}$ & ${ }^{24} \mathrm{Na}$ & 1369 & $15 \mathrm{~h}$ & 4662 & 2801 & 990 & $4289-920.9$ & 2803 & 1228 \\
\hline $\mathrm{Mg}$ & ${ }^{27} \mathrm{Mg}$ & 1013 & $9.64 \mathrm{~m}$ & 130.5 & 55.50 & 23.96 & $171.6-9.595$ & 79.92 & 43.4 \\
\hline $\mathrm{Al}$ & ${ }^{28} \mathrm{Al}$ & 1780 & $2.31 \mathrm{~m}$ & 6.643 & 3. 174 & 1.650 & $10.64-1.898$ & 5. 270 & 2.847 \\
\hline $\mathrm{Cl}$ & ${ }^{38} \mathrm{Cl}$ & 1642 & $37.3 \mathrm{~m}$ & 152.5 & 71.3 & 43.7 & $5213-48.5$ & 1260.7 & 1594.6 \\
\hline $\mathrm{K}$ & ${ }^{42} \mathrm{~K}$ & 1524 & $12.4 \mathrm{~h}$ & $\begin{array}{ll}4350 \\
-377.8\end{array}$ & 1422 & 933 & $1448-372.4$ & 867.8 & 333.1 \\
\hline $\mathrm{Sc}$ & ${ }^{46} \mathrm{Sc}$ & 889 & $83.9 \mathrm{~d}$ & $\begin{array}{c}4.51-0.37 \\
\left(\times 10^{-4}\right)\end{array}$ & 1. ${ }_{\times 10^{-4}}$ & 1. ${ }_{\times 10^{-4}}$ & $\begin{array}{r}3.36-0.52 \\
\left(\times 10^{-4}\right)\end{array}$ & 1. $\underset{\times 10^{-4}}{91}$ & 0. ${ }_{\times 10^{-4}}^{90}$ \\
\hline V & $52 \mathrm{~V}$ & 1434 & $3.75 \mathrm{~m}$ & $\left|\begin{array}{c}7.06-1.27 \\
\left(\times 10^{-2}\right)\end{array}\right|$ & 3. 43 & 1. 93 & $\begin{array}{l}7.06- \\
\left(\times 10^{-2}\right)^{*}\end{array}$ & 5. $\begin{array}{l}47 \\
\times 10^{-2}\end{array}$ & $0.25 \times 10^{-2}$ \\
\hline $\mathrm{Cr}$ & ${ }^{51} \mathrm{Cr}$ & 320 & $27.8 \mathrm{~d}$ & $\begin{array}{c}1.80-0.35 \\
\left(\times 10^{-2}\right)\end{array}$ & 0.99 & 0.42 & $\begin{array}{c}4.96-1.42 \\
\left(\times 10^{-2}\right)\end{array}$ & $\begin{array}{l}2.67 \\
\times 10^{-2}\end{array}$ & 1. $\times 13$ \\
\hline $\mathrm{Fe}$ & ${ }^{59} \mathrm{Fe}$ & 1292 & $45.6 \mathrm{~d}$ & $1.57-0.47$ & 1.06 & 0.36 & $1.52-c$ & 1. 16 & 0.44 \\
\hline Co & ${ }^{60} \mathrm{Co}$ & 1332 & $5.263 \mathrm{y}$ & $\begin{array}{c}4.77-1.30 \\
\left(\times 10^{-3}\right)\end{array}$ & $\begin{array}{l}2.62 \\
\times 10^{-3}\end{array}$ & $\begin{array}{l}0.97 \\
\times 10^{-3}\end{array}$ & $\begin{array}{l}1.68- \\
\left(\times 10^{-3}\right) *\end{array}$ & $\begin{array}{l}\text { 1. } 35 \\
\times 10^{-3}\end{array}$ & $\begin{array}{l}0.24 \\
\times 10^{-2}\end{array}$ \\
\hline $\mathrm{Zn}$ & ${ }^{65} \mathrm{Zn}$ & 1115 & $245 \mathrm{~d}$ & 14. $6-0.11$ & 1.87 & 3. 54 & 1. $69-$ & 0.88 & 0.28 \\
\hline $\mathrm{Se}$ & ${ }^{75} \mathrm{Se}$ & 265 & $120.4 \mathrm{~d}$ & $\begin{array}{c}6.91-0.90 \\
\left(\times 10^{-2}\right)\end{array}$ & 3. 22 & $\begin{array}{l}\text { 1. } \\
\times 10^{-2}\end{array}$ & $\begin{array}{l}47.9-4.35 \\
\left(\times 10^{-2}\right)\end{array}$ & 16. 0 & $\begin{array}{l}\text { 14. } \\
\times 10^{-2}\end{array}$ \\
\hline $\mathrm{Br}$ & ${ }^{80} \mathrm{Br}$ & 618 & $17.6 \mathrm{~m}$ & $6.834-0.329$ & 1.317 & 1.28 & 5. $35-$ & 2.632 & 1.447 \\
\hline $\mathrm{Rb}$ & ${ }^{86} \mathrm{Rb}$ & 1078 & $18.66 \mathrm{~d}$ & $5.19-0.30$ & 1.76 & 1. 32 & 1. $75-0.94$ & 1.33 & 0.27 \\
\hline $\mathrm{Sb}$ & ${ }^{124} \mathrm{Sb}$ & 720 & $60.4 \mathrm{~d}$ & $\begin{array}{c}1.04-0.36 \\
\left(\times 10^{-2}\right)\end{array}$ & $\begin{array}{l}0.77 \\
\times 10^{-2}\end{array}$ & $\begin{array}{l}0.29 \\
\times 10^{-2}\end{array}$ & $\begin{array}{c}25.6-5.07 \\
\left(\times 10^{-2}\right)\end{array}$ & 14. 9 × $10^{2}$ & 8. 40 \\
\hline Cs & ${ }^{134} \mathrm{Cs}$ & 796 & 2. $046 \mathrm{y}$ & 13. $\begin{array}{c}1-0.52 \\
\left(\times 10^{-3}\right)\end{array}$ & $\begin{array}{l}5.07 \\
\quad \times 10^{-3} \\
\end{array}$ & $\begin{array}{l}2.99 \\
\times 10^{-3} \\
\end{array}$ & $\begin{array}{r}9.53-3.43 \\
\left(\times 10^{-3}\right) \\
\end{array}$ & $\begin{array}{l}\text { 6. } 67 \\
\quad \times 10^{-3} \\
\end{array}$ & $\begin{array}{l}2.23 \\
\quad \times 10^{-3} \\
\end{array}$ \\
\hline
\end{tabular}

* The minimum value was below the detection limit in this work, namely $1.0 \times 10^{-2} \mu \mathrm{g} / \mathrm{ml}$ for $\mathrm{V}, 1 \times 10^{-3}$ $\mu \mathrm{g} / \mathrm{m} l$ for Co.

\section{Results and Discussion}

The results are summarized in Table 1 for 16 elements in terms of the concentration ranges and averages of 34 patients and 9 normal men. The standard deviations among the samples are also shown. The logarithms of the ratios of the elemental concentrations observed among the patients to those of the normal men are plotted in Fig. 1. The vertical lines with open circles show the ranges found among the normal men. From the figure it may be suggested that the chromium content in the urine of the diabetes patients is below normal as pointed out by $\mathrm{Mertz}^{2)}$, and that the selenium and cobalt contents are appreciably different from those of the normal men. In Fig. 2, is depicted how each elemental concentration varies among the individuals. The histograms are shown in terms of the percentage occurrence out of the total number of samples that could be analyzed in the present work, namely, above the detection limit for the respective element.

The abscissa is taken in unit of $\log (\mu \mathrm{g} / \mathrm{g})$. The normal men are shown by shaded histograms while the diabetes patients, by open ones. Wide variation of the concentrations among the individuals is typical for the urine samples but is not usually observed for the blood or serum samples $^{3)}$.

\section{Conclusion}

Urine samples from 34 diabetes patients and 9 normal men were analyzed by instrumental neutron activation analysis. It was found that the urine samples from the patients were rather deficient in chromium and selenium, and more abundant in cobalt. In order to make the conclusion more definite, it is suggested to analyze a larger number of samples taken from men on controlled diet. 

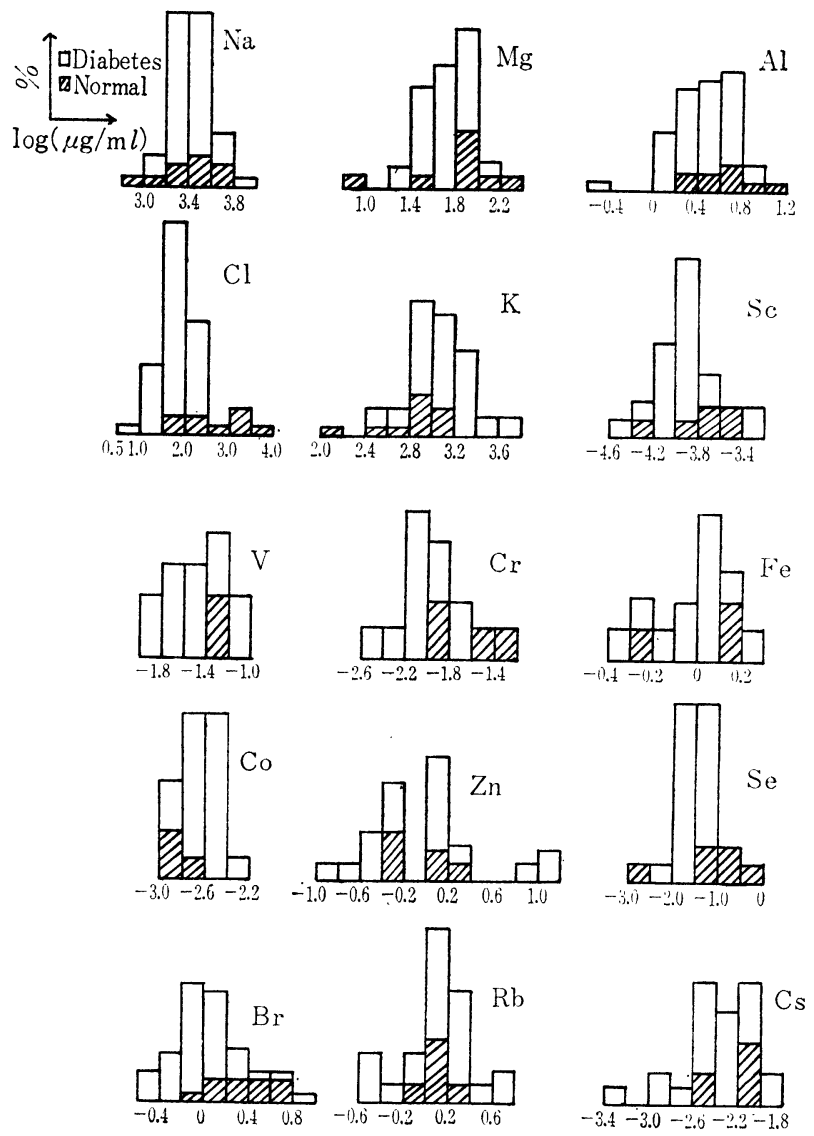

Fig. 1 Histograms showing the spread in elemental concentration among various urine samples.

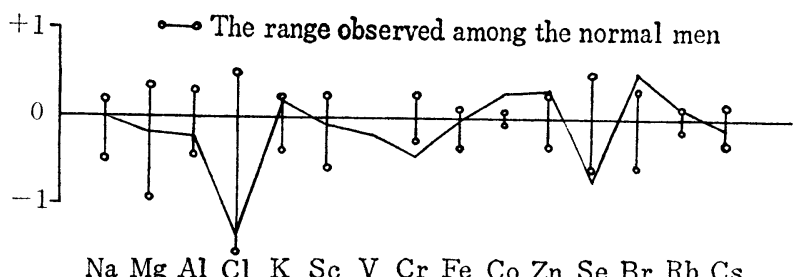

Fig. 2 Average concentrations of minor elements in urine observed among the diabetes patients shown in terms of $\log \left(\bar{x}_{D} / \bar{x}_{N}\right)$ where $\bar{x}_{D}$ and $\bar{x}_{N}$ denote the average value for patients and normal men, respectively.

The authors are indebted to Dr. A. Ohkubo, University of Tokyo for suggesting this work and for supplying the urine samples.

\section{References}

1) E.J. Underwood: Trace Elements in Human and Animal Nutrition, 3rd ed., Academic Press, New York and London, (1971)

2) W. Mertz: Physiol. Rev., 49, 163 (1969)

3) H. Nakahara, Y. Nagame, Y. Yoshizawa, H. Oda, S. Gotoh and Y. Murakami: $J$. Radioanal. Chem., 54, 183 (1979) 